\title{
THE FEDERAL BUDGET IN Q1 2016: REVENUES AND EXPENDITURES CONTINUE DOWNWARD TREND ${ }^{1}$
}

\author{
A.Mamedov, E.Fomina
}

During Q1 2016, the volume of the federal budget revenues shrank by 5.7 p.p. of GDP, in terms of expenditures the reduction hit 6.1 p.p. of GDP. Contraction of the revenue and expenditure part of the federal budget amounted to around 20\% in real terms. Fall of revenues in Q1 2016 was due to contraction of non-oil and gas receipts in the volume of 4.2 p.p. of GDP. Regarding expenditure, noticeable reduction has taken place in financing of defense and national economy along growth of expenditures on social safety net to the level of Q1 2015. The federal budget deficit has come to 3.7\% of GDP against 4.2\% of GDP posted in January through March 2015.

The federal budget revenues during January-March 2016 against the corresponding period of last year contracted by 5.7 p.p. of GDP (reduction constituted $24 \%$ in real terms) (Table 1). The structure of revenues saw an increase in the share of non-oil and gas proceeds in the federal budget from $55 \%$ to $66 \%$. However, this should be taken as a real decrease of oil and gas dependence of the budget: in substance, replacement of oil and gas revenues by non-primary ones has failed to materialize. Contraction of oil and gas revenues has reached $42 \%$ in real terms and non-oil and gas $-9 \%$. In other words, non-oil and gas component was decreasing slower.

Table 1

MAIN PARAMETERS OF THE FEDERAL BUDGET FOR JANUARY-MARCH 2015-2016

\begin{tabular}{|c|c|c|c|c|c|c|}
\hline & \multicolumn{2}{|c|}{$\begin{array}{l}\text { January-March } \\
2015\end{array}$} & \multicolumn{2}{|c|}{$\begin{array}{l}\text { January-March } \\
2016\end{array}$} & \multicolumn{2}{|c|}{ Change } \\
\hline & $\mathrm{Rb}$ bn. & GDP \% & $\mathrm{Rb} b n$. & GDP $\%$ & $\mathrm{Rb}$ bn. & $\begin{array}{l}\text { p.p. of } \\
\text { GDP }\end{array}$ \\
\hline Revenues, of which: & 3438.1 & 20.8 & 2908.4 & 15.1 & -529.7 & -5.7 \\
\hline - Oil and gas revenues & 1545.6 & 9.3 & 992.2 & 5.2 & -553.4 & -4.2 \\
\hline - Non-oil and gas revenues & 1892.5 & 11.4 & 1916.2 & 10.0 & 23.7 & -1.4 \\
\hline Expenditures, of which: & 4130.0 & 24.9 & 3621.3 & 18.8 & -508.7 & -6.1 \\
\hline - interest cover & 162.3 & 1.0 & 193.7 & 1.0 & 31.4 & +0.03 \\
\hline - noninterest costs & 3967.7 & 24.0 & 3427.6 & 17.8 & -540.1 & -6.2 \\
\hline $\begin{array}{l}\text { Surplus (deficit) of } \\
\text { the federal budget }\end{array}$ & -691.9 & -4.2 & -712.9 & -3.7 & -21.0 & +0.5 \\
\hline Non-oil and gas deficit & -2237.5 & -13.5 & -1705.1 & -8.9 & 532.4 & +4.7 \\
\hline GDP estimate & \multicolumn{2}{|c|}{16564.8} & \multicolumn{2}{|c|}{19254.9} & \multicolumn{2}{|l|}{ 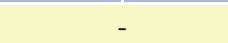 } \\
\hline
\end{tabular}

Sources: RF Finance Ministry (preliminary estimate), Federal Treasury (live data), own calculations.

The federal budget expenditures shrank by 6.1 p.p. of GDP over JanuaryMarch 2016 against the corresponding period of 2015. The volume of interest cover has remained at the Q1 2015 level (around 1\% of GDP). The real

1 This paper was originally published in Online Monitoring of Russia's Economic Outlook No.8(26). 
reduction of non-interest costs of the federal budget reached $22 \%$ during January-March 2016.

As a result, as of 1 April 2016, the federal budget was executed with a deficit totaling 3.7\% of GDP against 4.2\% of GDP over January-March 2015. However, it is important to understand that the observed significant federal budget deficit in Q1 2015 was to a large extent due to the outrun financing of the defense spending (cash execution in January-March 2015 amounted to $44 \%$ of the annual budget breakdown). Thus, the data on the deficit dynamics in real terms do not represent improvement of the situation with the budget execution.

The 2016 federal budget law has set the deficit amount totaling 3\% of GDP (calculating parting from $\$ 50$ per barrel price of oil). The amendments ${ }^{1}$ drafted by the RF Finance ministry into the effective law envisage retention of the deficit amount at the approved level amid reduction of the base price on oil to $\$ 40$ per barrel. In order to avoid growing 2016 federal budget deficit over and above the approved volumes, the federal budget resources will be replenished with proceeds obtained from the privatization of state assets ${ }^{2}$. Expected $10 \%$ reduction of the federal budget spending has also been envisaged. Moreover, it is planned to approve the volumes of targeted anti-crisis support provided to industry (automobile, transport and agricultural machine building, light industry, and housing and public utilities). However, the amendments will be submitted to the State Duma not earlier than the autumn session ${ }^{3}$. That will be done together with the draft of the federal budget for 2017-2019. The spending shift will be formalized via anti-crisis fund.

On the whole, during January-March 2016, the federal budget tax revenues (Table 2) fell by $21 \%$ in real terms against Q1 2015. Deterioration of dynamics in share of GDP and in real terms has happened across all types of tax receipts except excises on domestic products.

Table 2

MAIN TAX REVENUES IN THE FEDERAL BUDGET IN JANUARY-MARCH 2015-2016

\begin{tabular}{|c|c|c|c|c|c|c|}
\hline & \multicolumn{2}{|c|}{$\mathrm{Rb}$ bn } & \multicolumn{2}{|c|}{$\%$ of GDP } & \multicolumn{2}{|c|}{ Change } \\
\hline & $\begin{array}{c}\text { Q1 } \\
2015\end{array}$ & $\begin{array}{c}\text { Q1 } \\
2016\end{array}$ & $\begin{array}{c}\text { Q1 } \\
2015\end{array}$ & $\begin{array}{c}\text { Q1 } \\
2016\end{array}$ & $\begin{array}{l}\text { p.p. of } \\
\text { GDP }\end{array}$ & $\begin{array}{c}\text { In real terms } \\
\text { and Q1 } \\
2016 / 2015, \%\end{array}$ \\
\hline Total tax revenues, including & 2978.5 & 2594.1 & 18.0 & 13.5 & -4.5 & -21 \\
\hline Corporate income tax & 92.5 & 101.9 & 0.6 & 0.5 & -0.1 & -1 \\
\hline $\begin{array}{l}\text { VAT on merchandise } \\
\text { on the RF territory }\end{array}$ & 679.9 & 731.6 & 4.1 & 3.8 & -0.3 & -3 \\
\hline $\begin{array}{l}\text { VAT on merchandise imported } \\
\text { into the RF territory }\end{array}$ & 401.9 & 441.9 & 2.4 & 2.3 & -0.1 & -1 \\
\hline $\begin{array}{l}\text { Excises on merchandise man- } \\
\text { ufactured on the RF territory }\end{array}$ & 142.5 & 177.3 & 0.9 & 0.9 & 0.0 & +12 \\
\hline $\begin{array}{l}\text { Excises on merchandise } \\
\text { imported into the RF territory }\end{array}$ & 10.6 & 10.0 & 0.1 & 0.1 & 0.0 & -15 \\
\hline MET & 774.3 & 565.3 & 4.7 & 2.9 & -1.7 & -34 \\
\hline $\begin{array}{l}\text { Revenues generated by the } \\
\text { foreign economic activity }\end{array}$ & 846.8 & 538.7 & 5.1 & 2.8 & -2.3 & -43 \\
\hline
\end{tabular}

Sources: RF Treasury (current data), own calculations.

1 http://bujet.ru/article/296442.php

2 According to estimates, additional volume of proceeds to the deferral budget in 20162017 generated by privatization of such companies as Rosneft, Bashneft, ALROSA, and VTB will hit $\mathrm{Rb} 1-1.5$ trillion.

3 http://government.ru/news/22717/ 

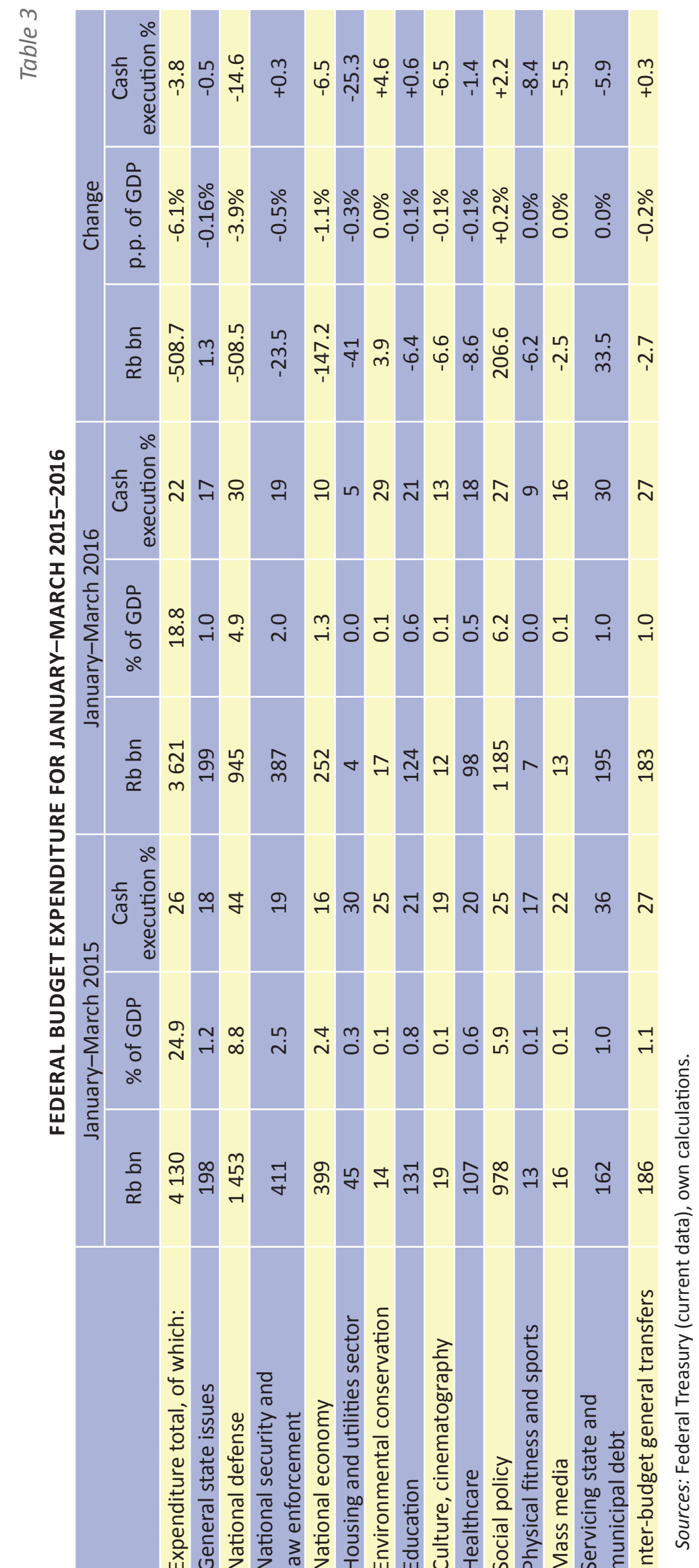
The utmost fall of revenues in Q1 2016 was accounted for the foreign economic activity -2.3 p.p. of GDP ( $43 \%$ in real terms). The main reason for the revenues decrease was the fall of the crude oil prices (average price during Q1 2016 - \$31.7 per barrel against $\$ 52.6$ per barrel in Q1 2015). The unfavorable dynamics of the crude oil prices has negatively affected on the crude oil export duty rates (average rate for January-March 2016 was at $\$ 55$ per ton, and for January-March 2015 - \$150 per ton). Decrease has taken place in spite of the fact that the base rate on crude oil export duty was retained at 2015 level (42\%) instead of previously envisaged by the tax maneuver its reduction to 36\% (from 1 January 2016). This decision was taken in late 2015 in order to prevent a more significant decrease of customs receipts in 2016.

In Q1 2016, contraction of proceeds generate by MET hit 1.7 p.p. of GDP (34\% in real terms). The reason for significant reduction has also been the fall of crude oil prices. Ruble's devaluation has failed to compensate for coefficient of world price dynamics. As a result, with the increase from 1 January 2016 the tax rate to Rb 857 per ton (in 2015 - Rb 799 per ton), the average rate of MET on crude oil and gas condensate (including coefficient Ky) for January-March 2016 fell to Rb 4,075.9 per ton (against Rb 6,872.5 per ton in Q1 2015).

Proceeds generated by excises demonstrated differently directed dynamics in Q1 2016 against the corresponding period of 2015. Revenues generated by excises from domestic products demonstrated real growth in the amount of $12 \%$, on imported merchandise, on the contrary, demonstrated contraction by $15 \%$. Growth of receipts generated by excises on domestic products was due to increased excises on tobacco products (excise rate growth on sticks was $30 \%)^{1}$. Reduction of receipts from excises on imported products was mainly due to a decrease of excises on automobiles and motorcycles (15\% in nominal terms).

Returns from other types of taxes in Q1 2016 turned out to be more stable. Contraction in real terms of receipts from corporate income tax, domestic VAT and VAT on imported merchandise happened in the range of $1-3 \%$ (or $0.1-0.3$ p.p. of GDP).

Table 3 provides results of the federal budget execution in Q1 2015-2016 broken down by function cost.

The volume of the budget spending in Q1 2016 is lagging behind the 2015 corresponding level by 6.1 p.p. of GDP. Reduction of the spending has been documented across lines: National defense (-3.9 p.p. of GDP), National economy (-1.1 p.p. of GDP, National security and law enforcement (-0.5 p.p. of GDP). At the same time, it should be noted that the current cash execution across expenditure on defense and national economy is significantly lagging behind the indices of Q1 2015.

On other budget items, reduction of financing has amounted not more than 0.1-0.3 p.p. of GDP. Against the background of contraction of spending on the majority of the federal budget items, the social spending have gone up by 0.2 p.p. of GDP. Moreover, their outstripping disbursement is noticeable, which exceeds the value of Q1 2015 by 2.2 p.p. of GDP.

On the whole, the results of the federal budget execution for Q1 2016 demonstrate the presence of significant issues in the budget system amid

1 In 2016, specific part of excise on sticks went up from Rb 960 to 1,250 per a thousand sticks, ad valorem share - from 11 to $12 \%$ of estimated cost. 
current unfavorable macroeconomic conditions. In these conditions the decision to submit amendments in the Law on the federal budget solely in the autumn is considered questionable. On the one hand, this allows to take into consideration the real state of the Russian economy in 2016 and actual flow of revenues over 8-9 months. In addition, one should bear in mind the fact that autumn amendments will be submitted already after the parliamentary elections. On the other hand, this leads to a situation when most of the year the law on the budget with unrealistic (from the point of view of current estimate and forecast) parameters is effective. 